\title{
Georg Lukács
}

\section{Bolsjevismen som moralsk problem}

Vi har ikke til hensigt her at beskæftige os med hverken mulighederne for bolsjevismens praktiske virkeliggørelse eller med de gavnlige eller skadelige virkninger af dens eventuelle magtovertagelse. Bortset fra at forfatteren til disse linjer slet ikke føler sig kompetent til at løse den slags problemer, synes det dog formålstjenligt med henblik på en klar formulering af spørgsmålet fuldstændig at se bort fra overvejelser over de praktiske konsekvenser: Afgorelsen er - som ved ethvert vigtigt spørgsmål - af etisk natur, og afklaringen af de etiske aspekter er netop fra et rent handlingsmæssigt synspunkt den væsentligste opgave for øjeblikket. Denne måde at formulere spørgsmålet på retfærdiggøres på den ene side af, at det hyppigst anvendte argument i diskussionen omkring bolsjevismen - nemlig hvorvidt den økonomiske og politiske situation er tilstrækkelig moden til, at den umiddelbart lader sig realisere - a priori fører os ud i et uloseligt problem. Efter min mening vil der aldrig kunne eksistere en situation, som kan erkendes med fuld sikkerhed og pả forhånd: Viljen, som stræber mod at nå sit mål umiddelbart og for enhver pris, er en integreret del af den »modne« situation $i$ mindst samme omfang som de objek tive betingelser. På den anden side kan erkendelsen af, at bolsjevismens sejr måske betyder adelæggelsen af store kulturelle og civilisatoriske værdier, aldrig være et afgørende modargument for dem, som slutter sig til bolsjevismen af etiske eller historisk-filosofiske grunde. De vil med eller uden beklagelse konstatere, at det forholder sig sådan, men da de indser, at dette er uundgåeligt, ændrer det - med rette - intet ved deres bestemte mål. For de ved, at en verdensomspændende omvæltning af værdier ikke kan ske uden ødelæggelse af gamle værdier, og deres vilje, der stræber mod skabelsen af nye værdier, tillægger sig selv tilstrækkelig styrke til rigeligt at kunne give fremtidens menneskehed kompensation for de tabte værdier.

Det kan herefter synes, som om der for en seriøs socialist ikke mere eksisterede noget etisk problem, forsåvidt som beslutningen til fordel for bolsjevismen ikke mere giver anledning til tvivl. For hvis betingelsernes umodenhed og tilintetgørelsen af værdierne ikke regnes for væsentlige hindringer, stiller problemet sig sandsynligvis således: Vi har mulighed for umiddelbart og uden det mindste kompromis at virkeliggøre det, vi er overbevist 
om er rigtigt. Kan det da være en god socialist, som i den situation foreslår os endnu en gang at tænke os om og vente lidt, som kort sagt taler til os om kompromis'er? Og når en ikke-bolsjevik stillet over for dette henviser til princippet om demokrati, som mindretalsdiktaturet bevidst og i følge sagens natur udelukker, reagerer Lenins disciple - idet de lader sig lede af én af deres leders udtalelser - ved at fjerne selve termen demokrati fra deres partis navn og program og slet og ret erklære sig for kommunister. Selve muligheden for at rejse det etiske problem afhænger således af, om man beslutter, at demokratiet blot er en del af socialismens taktik (som kampmiddel i den periode, hvor socialismen er i mindretal og kæmper mod de undertrykkende klassers legaliserede og illegale terror), eller det er en så nødvendig bestanddel af socialismen, at man ikke kan undertrykke det uden først at have gjort sig de etiske og historiske konsekvenser af en sådan handling klart. I det sidste tilfælde vil et brud med demokratiets princip for enhver bevidst $o g$ ansvarlig socialist udgøre et meget alvorligt etisk problem.

Kun få har haft klarsyn nok til at adskille Marx' historiefilosofi fra hans sociologi. Tilsvarende har man kun sjældent gjort sig klart, at de to kardinalpunkter i hans system - klassekampen og den socialistiske orden, som er bestemt til at gøre en ende på klasserne og enhver form for undertrykkelse - på trods af deres nok så snævre indbyrdes afhængighed er produkter af helt forskellige argumentationer og begrebssammenhænge. Erkendelsen af klassekampen, som betyder et gennembrud i den marxistiske sociologi, og i følge hvilken samfundsordenen altid har eksisteret og nødvendigvis altid har haft en drivkraft, peger på et af de vigtigste grundprincipper i det netværk, der binder den historiske virkelighed sammen. Det andet hovedpunkt udgør det utopiske postulat i Marx' historiefilosofi: Det er et etisk program for en ny fremtidig verden. (Marx' hegelianisme, som i for høj grad tenderer mod at anbringe virkelighedens forskellige elementer på samme niveau, har været medvirkende til at udviske denne forskel). Proletariatets klassekamp, der er bestemt til at fremkalde den nye samfundsorden, rummer endnu ikke i sig - i og med at den er klassekamp - den nye orden. Af den kendsgerning at proletariatets frigørelse udrydder kapitalistklassens undertrykkelse følger ikke udryddelsen af enhver klasseundertrykkelse, lige så lidt som en sådan total afskaffelse af undertrykkelsen blev resultatet af borgerklassens sejrrige befrielseskampe. Anskuet ud fra en isoleret sociologisk betragtningsmåde betyder den blot en forandring i klassestrukturen, en forvandling af de tidligere undertrykte til undertrykkere. For at dette mønster ikke skal gentage sig, for at den sande friheds æra, hvor der hverken findes undertrykkere eller undertrykte, skal kunne oprinde, er det godt nok en nødvendig forudsætning, at proletariatet sejrer, for dermed muliggøres frigørelsen af den sidste undertrykte klasse, men denne sejr kan aldrig være mere end en for udsætning, en negativ kendsgerning. For at fri- 
hedens æra skal blive til virkelighed, er det nødvendigt - udover at erkende de sociologiske kendsgerninger og love, som ikke af sig selv medfører den - at ville denne nye verden: Den demokratiske verden. Denne vilje er - netop fordi den ikke er en automatisk konsekvens af den sociologiske erkendelse - et så væsentligt element $\mathrm{i}$ den socialistiske verdensopfattelse, at den ikke lader sig fjerne uden fare for, at hele konstruktionen styrter sammen. For det er denne vilje, som gør proletariatet til bærer af menneskehedens samfundsmæssige forløsning, til verdenshistoriens Messias-klasse. Uden denne messianske patos havde social-demokratiets mageløse triumftog været utænkeligt. Og når Engels i proletariatet så den klassiske tyske filosofis arvtager, gjorde han det med rette, for med proletariatet blev Kant og Fichtes etiske idealisme omsider omsat til handling - en idealisme, som undertrykte enhver jordisk tilknytning og metafysisk ville rive den gamle verden løs fra dens forankring. Kun således blev det til handling, der hos dem ikke var andet end tanke; säledes kunne det rette sig direkte mod målet, som hos Schelling gennem æstetikken og hos Hegel gennem statsteorien blev ført væk fra fremskridtets vej for at ende i reaktion. Selvom Marx fremstillede denne historisk-filosofiske proces på hegelsk manér (List der Idee)", nemlig på den måde at det er ved at kæmpe for sine umiddelbare klasseinteresser, at proletariatet ender med at befri verden for al despotisme, så er det dog umuligt i afgørelsens øjeblik - og det er netop nu og her - at overse adskillelsen mellem den golde empiriske virkelighed og viljen, som er etisk, utopisk og menneskelig. Det er her, det vil åbenbares, om socialismens frigørende rolle består i at være den på én gang tvungne og frivillige bærer af verdens forløsning, eller om den blot er en ideologisk indpakning af klasseinteresser, som kun adskiller sig fra andre klasseinteresser ved deres indhold og ikke ved deres kvalitet eller moralske kraft. (Det 18. århundredes borgerlige frigørelsesteorier proklamerede og troede på samme måde på verdens forløsning, for eksempel gennem den frie konkurrence; men den kendsgerning, at det her blot drejede sig om en ideologi konstrueret på basis af klasseinteresser, blev ikke afsløret, før den franske revolution var $i$ fuld $t$ udbrud - i afgørelsens øjeblik).

Hvis altså den samfundsorden, som ikke kender til klasseundertrykkelse - det rendyrkede social-demokrati -, blot var en ideologi, var der i dette øjeblik ingen grund til at tale om moralske problemer og moralske dilemmaer. Det moralske problem fremkommer præcis ved den kendsgerning, at for social-demokratiet er det sande endemål for al kamp, det mål, som afgør alt og er kronen pà alt, det følgende: Den overordnede mening med proletariatets kamp er i fremtiden at umuliggore enhver klassekamp, at skabe en samfundsorden, hvor klassekamp ikke kan forekomme, ikke engang i tankens form. Her står vi sả betagende nær ved virkeliggørelsen af dette mål, og det er netop i denne nærhed, at det etiske dilemma har sit ud- 
spring. Enten griber vi chancen for at virkeliggøre målet og derved bevæger vi os nødvendigvis ind på diktaturets, terrorens og klasseundertrykkelsens område. Vi må erstatte de foregående klassers herredømme med proletariatets klasseherredømme og tro på, at Belsebub vil uddrive Satan, at dette sidste klasseherredømme, som i følge sin natur er det mest grusomme og mest åbenlyse, vil ødelægge sig selv og dermed ethvert klasseherredømme. Eller også holder vi fast ved, at den nye samfundsorden skal realiseres med nye midler - med det sande demokratis midler (for det sande demokrati har hidtil kun eksisteret som fordring, aldrig som realitet - ikke engang i såkaldt demokratiske stater). Men i så fald risikerer vi at støde på det forhold, at det store flertal af menneskeheden endnu ikke ønsker denne nye samfundsorden indført her og nu, og da vi ikke ønsker at bestemme over dem mod deres vilje, så må vi vente, uddanne, opdrage og udbrede troen i ventetiden indtil det tidspunkt, hvor menneskeheden endelig bestemmer over sig selv, er fri i sin vilje og skaber den samfundsorden, der længe har været ønsket af dem, som var bevidst derom, og for hvem den var den eneste løsning. Det etiske dilemma kommer af, at begge holdninger $i$ sig rummer mulighed for frygtelige forbrydelser og umådelige fejltagelser, men den, der føler sig forpligtet til at vælge, må bevidst og til fulde påtage sig ansvaret for dem. Den fare, som den sidstnæunte holdning indebærer, er helt indlysende: Det drejer sig om nødvendigheden af midlertidigt at samarbejde med klasser og partier, som kun er enige i visse af social-demokratiets umiddelbare mål, men som er fjendtligt indstillet over for dets endemål. Opgaven er så at finde en form, hvorunder dette samarbejde kan foregå, uden at målets renhed og viljens patos over for at virkeliggore det mister blot det mindste af sit væsen. Muligheden for fejltagelser og farer ligger i, at det er meget vanskeligt, næsten umuligt at afvige fra den lige og direkte vej til virkeliggørelsen af en hvilken som helst overbevisning, uden at denne afvigelse tilriver sig en vis autonomi, og uden at den tilsigtede formindskelse af virkeliggørelsestempoet øver indflydelse på viljens patos. Det dilemma, som kravet om demokrati stiller socialismen overfor, er et ydre kompromis, som ikke må blive til et indre kompromis.

Bolsjevismens fascinerende styrke kan forklares ved den befrielse, som følger af at udelukke dette kompromis. Men de, som er forblindet af denne mulighed, er måske ikke altid bevidst om det ansvar, som så påhviler dem. Deres dilemma bliver det følgende: Kan man opnå det gode gennem onde fremgangsmåder, kan man opnă friheden gennem undertrykkelse? Kan en ny verden fødes, når midlerne til at virkeliggøre den kun i teknisk henseende adskiller sig fra den gamle verdens med rette forhadte og foragtede midler? Det ser ud, som om man i dette tilfælde kunne henvise til den erkendelse, som den marxistiske sociologi har gjort, nemlig at historiens udvikling altid har bestået $\mathrm{i}$ kampen mellem undertrykte og undertrykkere, og at det altid 
vil være sådan; at selv proletariatets kamp ikke kan unddrage sig denne »lov«. Men hvis det var rigtigt, så ville - som ovenfor nævnt - hele socialismens åndelige indhold, bortset fra opfyldelsen af proletariatets umiddelbare materielle interesser, blot være ideologi. Dette er umuligt. Og eftersom det er umuligt, kan man ikke ophøje erkendelsen af en historisk kendsgerning til støttepille for den moralske vilje, viljen til at opbygge den nye samfundsorden. Det er nødvendigt at acceptere det onde som ondt, undertrykkelse som undertrykkelse og det nye klasseherredømme som klasseherredømme. Og det er nødvendigt at tro - og det er i sandhed credo quia absurdum est ${ }^{21}$ - at denne undertrykkelse ikke påny vil afføde de undertryktes kamp for at opnå magt (for muligheden for ny undertrykkelse) og så fremdeles en uendelig række af evige kampe uden măl og mening, men tværtimod at undertrykkelsen vil afskaffe sig selv.

Valget mellem de to holdninger er altså - som ved ethvert spørgsmål af moralsk art - et spørgsmål om tro. For et gennemborende blik, der i netop dette tilfælde måske ville vise sig at være overfladisk, kunne det tage sig ud som om, at når så mange gamle og prøvede socialister afviser den bolsjevistiske holdning, er det fordi deres tro på socialismen er blevet svækket. Jeg vedgår åbent, at det tror jeg ikke på. For jeg tror ikke på, at den bolsjevistiske beslutnings »barske heroisme« kræver mere tro end den langsomme kamp, der tilsyneladende er mindre heroisk, men som der dog påhviler et tungt ansvar, den kamp, som langsomt og pædagogisk bearbejder sjælen, og som føres af den, der til den yderste konsekvens tager demokratiet på sig. Den førstnævnte holdning tillader den enkelte uanset omkostningerne at bevare sin umiddelbare overbevisnings tilsyneladende renhed, mens denne renhed i den sidstnævnte holdning bevidst of res, for at man - alt imens man ofrer sig selv - kan virkeliggøre social-demokratiet $i$ dets totalitet og ikke blot et af dets aspekter, et af dets fragmenter løsrevet fra sit centrum. Jeg gentager: Bolsjevismen hviler på den metafysiske hypotese, at det gode kan udspringe af det onde, og at det er muligt, som Rasumikhin siger i Raskolnikov, at komme frem til sandheden ved at lyve. Forfatteren til disse linjer er ude af stand til at dele denne tro, og der for ser han et uløseligt moralsk dilemma i selve udgangspunktet for den bolsjevistiske holdning, mens han mener, at demokratiet af dem, som vil realisere det bevidst og ærligt til det sidste, kræver overmenneskeligt afkald og selvopofrelse. Men skønt denne holdning kræver overmenneskelig styrke, er den dog ikke i bund og grund uløselig, sảdan som det er tilfældet med det moralske dilemma, der rejses af bolsjevismen.

\section{Noter}

1. På tysk i originalen. Hegel taler egentlig om fornuftens, og ikke ideens list (o.a.) 
2. Jeg tror, fordi det er mod fornuften (o.a.)

(Artiklen oprindelig trykt i Szabad Gondolat, december 1918. Fordanskning af Rita Kiss og Martha Dufournauds franske oversættelse ved Preben Kaarsholm). 